\title{
Incorporating remanufacturing into the End-of-Life Vehicles Directive: Current presence and the waste problem
}

\author{
David A.P. Paterson ${ }^{1}$, Chih-Chuan Kao ${ }^{1}$, Winifred L. Ijomah ${ }^{1}$, James F.C. Windmill ${ }^{2}$
}

1 Design Manufacture and Engineering Management / University of Strathclyde 75 Montrose Street, G1 1XJ, Glasgow, Scotland, United Kingdom

2 Dept. of Electronic and Electrical Engineering / University of Strathclyde 204 George Street, G1 1XQ, Glasgow, Scotland, United Kingdom

Email: david.a.paterson@strath.ac.uk, Chihchuan.kao@strath.ac.uk, W.1.ijomah@strath.ac.uk, James.windmill@strath.ac.uk

Corresponding Author: David Paterson

Keywords: Remanufacturing, End-of-life vehicles, ELV, European Union, EU,

\begin{abstract}
Within the End-of-Life Vehicles (ELV) directive, various terminology and practices are outlined to ultimately divert waste from landfill, including reuse, recycle, recovery, treatment, prevention and economic operators. Remanufacturing terminology is not explicitly stated however. Further, leading global automotive remanufacturers, have recently agreed upon a collective definition of what constitutes automotive remanufacturing. With a view to establishing remanufacturing as a stand-alone process within the ELV directive going forward, this research analyses where remanufacturing is currently situated within the ELV directive, highlighting obstacles, with a strong focus on 'waste terminology', of directly incorporating remanufacturing into the ELV directive and presents guidance on incorporating remanufacturing moving forward. By ignoring the concept of waste, this study found that remanufacturing processes are generally classed under reuse, recycling and recovery terminology with remanufacturing also having a tenuous relationship with treatment facilities and economic operators. In addition to highlighting the issues caused by remanufacturing spanning across recycle and reuse terminology, by incorporating waste, this research also found that automotive associations definition of remanufacturing is not able to be incorporated into the ELV directive directly. A workable solution, taking both the objectives of the ELV directive and the view of the automotive associations into consideration, was however found, and is presented in this work.
\end{abstract}

\section{Introduction}


The End-of-Life Vehicles (ELV) directive [11] is a key strategy in tackling the large amount of waste vehicles generated within the EU each year - between 2006 and 2014 EU member states recorded approximately 59 million tonnes [14]. The key focus of the ELV directive is to force vehicles away from landfill and towards product and material recovery strategies such as recycle and reuse. Further, the ELV directive also places high disposal avoidance expectations (disposal being any operation which is not a recovery operation) on member states; consider targets applicable for 2015 (on onwards) that state a minimum of $95 \%$ (per average weight of vehicle) should be subjected to reuse and recovery and that a minimum of $85 \%$ (per average weight of vehicle) should be subjected to reuse and recycling per year.

To tackle other forms of waste, for example municipal and electronic and electrical, the EU has also introduced additional directives such as the Waste Framework (WF) directive [12] and Waste of Electrical and Electronic Equipment (WEEE) directive [13]. Similar to the ELV directive, strategies to avoid disposal such as recycling, recovery and reuse are again identified. The process of remanufacturing is however not discussed in the ELV, the WF or WEE directive directly or indeed in any EU directive.

Given that remanufacturing restores used products to at least virgin like performance and returns them to the market place with a warranty at least as good as original [18-19, 22, $25-26,33]$ the absence of remanufacturing in the ELV directive is of particular interest, especially when the established footprint that remanufacturing has in the automotive industry is considered.

With a view to establishing remanufacturing as a stand-alone process within the ELV directive going forward, this research seeks to identify the compatibility of remanufacturing, as agreed upon by leading global automotive remanufacturing associations, within the current ELV directive. This research investigates where remanufacturing currently resides within the ELV directive, identifies obstacles, with a strong focus on 'waste' terminology, to the insertion of remanufacturing directly into the ELV directive presents a workable solution to incorporating remanufacturing moving forward.

The structure of this research is thus; firstly a frame of reference is provided by documenting the definition of remanufacturing as agreed upon by leading global automotive remanufacturers. Justification for this research is then given. Following this, through examination of the various landfill avoidance strategies within the ELV directive, this manuscript presents for the first time in literature, an analysis of where remanufacturing currently resides with the ELV directive. The obstacles of incorporating remanufacturing into the ELV directive directly are then presented with the issues of waste taking a strong focus. Moving forward, a workable solution to the introduction of remanufacturing as a standalone process within the ELV directive is presented. Lastly, a conclusion is presented.

\section{Remanufacturing Definition}

Remanufacturing is both established terminology and an established process, but is on occasion used ambiguously. Consider [28], who identified literature which fails to separate remanufacturing from refurbishing and recondition or [16], who found that remanufacturing in 
the aerospace industry is sometimes referred to as rebuilding.

Given that this research investigates the presence of remanufacturing in the ELV directive, a recently agreed upon definition of remanufacturing from leading global automotive remanufacturing associations, [3], is presented in this work. Supporting this robust definition is an additional two matching definitions from literature $[5,8]$. These definitions are given in Table 1.

\section{INSERT TABLE 1}

Remanufacturing is commonly conducted on products referred to as cores. The automotive associations, define a core as,

"A core is a previously sold, worn or non-functional product or part, intended for the remanufacturing process. During reverse logistics, a core is protected, handled and identified for remanufacturing to avoid damage and to preserve its value. A core is not waste or scrap and is not intended to be reused before remanufacturing" [4],

While not explicit in the above definition in that a single product may be classed as a core, typically a core is series of assembled components, for example an automotive engine. [29], describe a core as a

“...product constructed through a manufacturing assembly process involving different parts "'[29],

Further, a typical remanufacturing operation involves 6 generic processes; (1) acceptance and cleaning of a core, (2) the disassembly or stripping of a core, (3) the cleaning of core components, (4) rebuilding, restoration and replacement of non-remanufacturable core parts, (5) core assembly or re-assembly and (6) core testing [5, 21-23, 27-29, 31, 33]. Figure 1 is given to reinforce the general process of core remanufacture.

\section{INSERT FIGURE 1}

Moving forward, the importance of understanding the role of remanufacturing in the ELV directive is now discussed. 


\section{The importance of promoting remanufacturing as a standalone processes within the ELV directive}

The main drivers for promoting remanufacturing within the ELV directive are a) the environmental benefits of remanufacturing, $b$ ) the removal of ambiguity in process, and c) the reduction in waste. Each area is now discussed.

Given the focus the ELV directive places on the minimisation of environmental impact of ELV's and on improving energy convservation, the environmenal benefits of remanufacturing offer significant solutions here; Sutherland et al, [35] predicted substantial energy savings when comparing remanufactured and virgin manufactured diesel engines, The Automotive Parts Remanufactures Association (APRA) [2], state that rebuilt or remanufactuered engines save over $50 \%$ of the energy compared to the production of new engines, while Sundin et al [34], found through case study analysis of various European wide practicing remanufacturers that energy savings, in some cases extreme savings of up to $85 \%$, can be found in some automotive remanufactured products. Additionally, Sundin and Lee [32], examined remanufacturing and the environment and identified further literature to document energy savings associated with gearboxes, alternators and truck injectors.

Looking now at ambiguity in definition. If remanufacturing or remanufacturing processes are residing ambigously within cross national legislation, difficulties in quickly gauging the remanufacturing market can begin to develop. For example, given that the EU documents recycling, reuse and recovery rates each year, (http://ec.europa.eu/eurostat), if remanufacturing process were included under recycling, reuse and recovery, it is entirely feasible that these statistics to some degree are defining remanufacturing processes, thus an additional barrier for gauging true remanufacturing market is introduced. An additional validation of this concept is documented by Lund and Hauser [25]. The authors found that previous research, [24], had overestimated the size of the american remanufacturing industry by virtue of a liberal definition of remanfacturing and by relying on a supply of information from trade associations who reported only very loose remanufacturing processes as remanufacturing.

An additionally point stemming from this argument is that along with issues such as branding and price, ambiguity over definition can affect the customers decision to purchase remanufactured products $[1,18,20]$. Thus, establishing remanufacturing as a standalone disposal avoidance strategy would in part help to alleviate confusion over performance and quality, in that remanufactured products would be clearly identified with remanufacturers being accountable to meet set standards.

In terms of waste reduction, additional justification can be drawn from the ELV directive itself. Consider, article 4 point 1(c) of the ELV directive,

"Vehicle manufacturers, in liaison with material and equipment manufacturers, to integrate an increasing quantity of recycled material in vehicles and other products, in order to develop the markets for recycled materials." 
Given a large amount of products able to be remanufactured, such as engines, compressors, starter motors, brake callipers, power steering pumps, distributors, hydraulic pumps and gear boxes, [6], remanufacturing produces parts directly suitable for incorporation into new vehicles and components. Further, there is no doubt in the performance of remanufactured products, they are 'as good as new', which is not necessarily the case for recycled products, and so by encouraging vehicle manufactures to use 'as good as new' or remanufactured products there follows less objection to integrating these parts in new products on grounds of product quality concerns.

Lastly, recent external precedent also supports the concept that remanufacturing should be defined as a standalone process; consider the United States Government Federal Repair Cost Savings Act, [15]. The repair cost savings act states that the head of each federal agency is encouraged to use remanufactured vehicle components to maintain federal vehicles, where remanufacturing does not reduce vehicle quality or vehicle restoration time and is financially advantageous. Thus, existing precedent encouraging remanufacturing within the automotive industry is identified, and if we take into consideration the potential implementation of remanufacturing terminology into the WF directive, [9], then future remanufacturing terminology being introduced in the ELV is a distinct possibility. Future terminology of course would define remanufacturing legally, and so additional rationale as to why it is important for remanufacturing to emerge from the existing practices is identified.

\section{Where remanufacturing resides within the ELV directive}

Table 2 identifies key terminology upon which the goals of the ELV directive are built upon. Additionally, the relationship this terminology has to the remanufacturing definition agreed upon by the automotive associations, from the perspective of the authors, is also given.

\section{INSERT TABLE 2}

Prior to discussing the findings from Table 2, it should be stated in the first instance that the concept of waste was ignored. The issue of regarding cores as waste or non-waste and the subsequent impact, is presented after this discussion.

From Table 2, it is evident that remanufacturing is indirectly accounted for in the ELV directive, and is able to be potentially thought of as a prevention operation, a treatment operation, a reuse operation, a recovery operation, and a recycling operation. Further, remanufactuers liberally could also in some circumstances be classed as producers, economic operators, and treatment operators, noting that in the last case they should be supplied with correct vehicle dismantling information. Each subject is now briefly discussed

Considering first, prevention. The theme of prevention is to reduce the amount and environmental impact of End-of-Life (EoL) vehicles, substances and materials. With remanufacturing offering energy and material savings, and able to return a used product back 
to the market place at a competitive price, it is clear that remanufacturing is capable of being classed as a prevention measure.

As for reuse, recycling and recovery. Recovery is defined as any operation from a list of operations outlined in a 1975 waste directive [7]. This directive is a forerunner to the WF directive [12] and so, the actual recovery operations are listed in the latter directive. The WF directive recovery operations listed, are not generally akin to the process of remanufacturing, however the WF directive states that this list is non-exhaustive and gives a definition of a recovery operation - given as $2.8^{* *}$ in Table 2 . Using this definition, then it is evident that remanufacturing could be classed as a recovery operation, again if the concept of waste is ignored.

Defintion 2.6 identifies reuse as any operation in which components of ELV's are used for the same purpose for which they were conceived. Remanufacturing, in the authors' opinion falls within this category. Further, it is also the case that reuse terminolgy allows for instances of a restored component (as a result of remanfuacturing) being used in the manfuacture of a new core, or in the rebuilding of a different core.

In the case of recycling, remanufacturing processes could also liberally fall under recycling terminolgoy of the ELV. While remanufacturing is a distinct process separate from recycling, given that remanufactured materials are reprocessed in a production process for the original or other purpose, an argument can be made to suggest a liberal association with remanufacturing and recycling in this instance. Additionally, recyling is thought of as a form of recovery operation, therefore classing recycling as a recovery operation, to some extent forces remanufacturing, which is a recovery operation, to therefore to have some degree of relationship to recycling.

Looking now at definition 2.5. Treatment is defined as any activity carried out for the recovery and/or disposal of ELV's once they have been handed over to a treatment facility. Owing to the potential for remanufacturing to be classed as a recovery operation, remanufacturing must also therefore have the potential to be classed as a treatment operation. Further, similar to previous argument, if remanufacturing processes are being conducted at treatment facilities, there is potential for treatment facilities to be classed liberally as remanufactuing facilities in some cases. Further, definition 2.10 states that recoverers, recyclers, and treatement operators, are classed as economic operators. Therefore, using the arguments already laid out, similar to treatment operators, economic operators are, in some circumstances, could be liberally classed as remanufacturers. Figure 2, outlines graphically the various processes and definitions which could in some cases incorporate remanufacturing processes.

\section{INSERT FIGURE 2}

Note that Figure 2 involves a heirarchy system; recycling, recovery and reuse are classed as treatment operations, treatment operators are classed as economic operators, and economic operators fall within prevention measures. 
It must be stated however that while remanuacturing falls under recycling, reuse and recovery operations, not every recycling, reuse or recovery operation is remanufacture and therefore under no circumstances should recycling, reuse and recovery be used interchangebly with remanfuacturing. Consider for instance, recycling a plastic bottle. The bottle is recycled via being melted down and a new product can be manuactured. This is not in any circumstances a remanufacturing process. However, if a core component is cleaned, disassembled, had it's core components restored, rebuilt or perhaps even replaced or reprocessed to create new products, and then rebuilt and so no longer constitues a waste, then the original core component could perhaps be considered to be reprocessed in a production processes (definition of recycle within ELV) to a given degree. More often than not, recycling will not overlap with remanfuacture, however, owing to remanufacturing not being defined in the ELV, potential exists for current degrees of overlap to be apparent. A similar argument holds for reuse and recovery, and for treatment operations.

The conclusion is that given a lack of explicit remanufacturing terminolgy in the ELV directive, remanufacturing being a legitimate disposal avoidance strategy is forced to have a presence in prevention measures, recycling, recovery and reuse with remanufacturers themselves able to be classed in some circumstances liberally as economic operators and treatment operators.

\section{Evidence of waste in remanufacturing definitions}

Examining now the concept of waste and non-waste; the remanufacturing definitions outlined in Table 1 are in reference to waste are examined

The automotive associations [4], state that remanufacutring returns cores, issused with a full warranty, to as good as new standard; which is expected. However, the automotive associations state that a core is not waste or scrap, while also stating that a core should not be reused proir to remanufacturing. It is clear that the automotive associations do not class cores as waste, and thus remanufacturing should occur on products or cores that are not classed as waste.

Reviewing now the BSI definition [5], there is no direct indication that remanufacturing is required to be exclusively conducted on products or cores classed as waste. The definition only states that remanufacturing is conducted on used products, thus both waste and non-waste could fall within this category.

Looking now the last definition in Table 1, [8]. This definition states that a series of manufacturing steps (typically the remanufacturing processes) are conducted on an EoL part or product. There is no further explanation of whether EoL is thought of as waste, however, if the European Action Plan is read in conjunction with the ELV directive, then it is reasonable to assume that EoL in this case refers to ELV's, which are indeed waste.

It can be said therefore, that the three definitions have alternating views on whether remanufacturing is conducted on waste. The automotive associations definitively state that remanufacturing is conducted on products which are not waste, the BSI defnintion is not explicit in stating that used products should be classed on waste or non-waste, just that they 
are previously used, and the European Action Plan infers that remanufacturing is conducted on waste if read in conjunction with ELV directive, but other wise has no preference.

Judging by the principle that parts created specifically for vehicles are subject to the ELV directive and not other directives, [10], the distinction from the automotive associations that cores are not waste is very important when seeking to implement remanufacturing into the ELV directive.

\section{Obstacles to incorporating remanufacturing into the ELV directive}

\section{Waste problem}

By setting aside the issue of waste, this research has shown that remanufacturing processes are to some degree embedded into recycling, recovery and reuse operations of the ELV directive. Examining now the issue of waste, obstacles to incorporating remanufacturing into the ELV directive are apparent. Consider the following scenarios.

Automotive remanufacturers such as an original equipment manufacturer (OEM) may offer a leasing or rental based business model. In this circumstance, the registered keeper of the vehicle (the person who is using the car) does not own the vehicle but instead the vehicle owner is the party who is leasing or renting the car to the registered keeper i.e. the OEM. Under this system, when the registered keeper returns the vehicle to the registered owner, the vehicle is not waste, given that the registered keeper cannot discard something that they do not own. Therefore an OEM remanufacturer can potentially conduct remanfuacturing operations on non-waste vehicles. (which is in line with the automotive associations description of a core).

Now consider an independent remanufacturer (IR) who may obtain vehicle components from an authorised treatment facility (ATF); noting that when the vehicle reaches the ATF, it is considered a waste. In this instance, the ATF has a responsibility under the ELV to ensure they meet targets (\% by weight) for reuse and recovery of ELV's. Thus, if an IR conducts remanufacturing operations, see figure 1, they are doing so on cores which are considered as waste.

Analysing these scenarios, and looking first at the OEM example. Remanufacturing in this instance is conducted on non-waste. While this is acceptable from the view of the automotive assoications, this is not generally acceptable from the persepective of the ELV directive; given that ELV directive is focused on waste avoidance any recovery strategy housed within the directive can presumably only apply to waste. Thus, a fundamental conflict appears within literature; from the ELV directive perspective, remanufacturing would only occur at the waste stage, whereas from the automotive associations perspective, remanufacturing would only occur at the usage stage i.e. before the products become waste. This distinction stops the automotive associations definition of remanufacturing being adopted unabridged into the ELV directive.

Examining now the case of the IR who obtain cores from an ATF and perform remanufacturing operations (figure 1). Given that the cores are taken from an ATF, the cores must be thought of as waste, thus remanufacturing in this instance is not in agreement with 
how automotive associations view remanfuacturing. Again, difficulty in adopting the remanufacturing definition from the automotive associations unabridged is shown.

\section{Establishing remanufacturing as a stand alone strategy}

In addition to the issues accociated with waste, establishing remanufacturing as a standalone waste avoidance strategy is a further hurdle that needs adressed.

Given that recycle, reuse and remanufacturing are understood as separate processes within literature $[17,21,23,26-30]$ and noting that literature's opinion or viewpoint is formed by studying operations conducted within industry, it is important to remain consistent with existing litearture. However, it has thus far been shown that remanufacturing has potentially a presence in recycle and reuse, which are both recovery operations of the ELV directive. It can be stated therefore that in addition to incorporating an abridged version of the remanufacturing definition from the automotive assoications into the ELV directive, further work is also required to clearly separate remanufacturing from recycle and reuse.

Additionally, consider the stipulation of the ELV directive that dismantling information is all the necessary information required for the environmentally sound treatment of ELV's and that treatment facilities should have this information given to them from vehicle manufacturers. Thus, if remanufacturing is defined as a recovery process within the ELV directive and is performed at treatment facilities, vehicles manufactureres may be obligated to supply key information concerning dissassembly and reassamebly to support the remanufacturing operations conducted at the treatment facilities, information that vehicle manufacturers may be reluctant to divulge.

\section{Incorporation of remanufacturing into the ELV directive}

\section{Waste problem}

It has thus far been shown that given the objective of the ELV directive to divert waste from landfill and towards recovery, the insistance of cores being non-waste stops the incorporation of remanufacturing terminology being inserted un-abridged into the ELV directive at present. Further, should the ELV directive somehow incorporate remanufacturing, a conflict in terms of which life cycle stage remanufacturing occurs at would be developed within literature.

On first thought, the natural solution to this problem is to abridge the definition from the automotive associations and define remanufacturing as being able to occur on both waste and non-waste, a situation similar to Ijomah (2002), [21], in which the terminology of 'used products' is used.

This decision would satisfy the situation of when IR conduct remanufacturing on cores obtained from an ATF, thus allowing remanufacturing to emerge from behind reuse, recycle and recovery terminology. Also, given that other types of remanufacturing, by for 
example OEM remanufacturers, occur at the usage stage of the product life cycle, stipulating that remanufacturing can occur on waste and non-waste within the ELV directive, would thus not infringe on the remanufacturing definition as outlined by the automotive associations; in this instance, the definition from the ELV would be in part agreement with the definition from the automotive associations.

On closer examination however, stipulating that remanufacturing can occur on nonwaste may not actually be feasible given that waste permeates right through the ELV directive. Specifically, given the focus of waste being diverted from landfill within the ELV directive, any inclusion of a remanufacturing definition within the ELV directive must by definition force remanufacturing to occur solely and strictly on waste products only. It can be stated therefore that there is not a scenario at present which would allows a cross body agreement between ELV directive and the automotive associations in terms of how remanufacturing is defined, or more specically which stage in the life cycle remanufacturing occurs.

The authors put forward, that given remanufacturing is a viable option for restoring products to as new standard, remanufacturing terminology should be adopted into the ELV directive, therefore the non-waste requirement from the automotive associations must be eliminated from a future definition. An example of such a definition is given below,

"Remanufacturing is a standardized industrial process by which cores are returned to sameas-new, or better, condition and performance. The process is in line with specific technical specifications, including engineering, quality and testing standards. The process yields fully warranted products. "[3]

"A core is a previously used product or part, intended for the remanufacturing process."

This would satisfy the ELV directives objectives and goals, and start the process of remanufacturing emerging from behind other recovery strategies. The unavoidable drawback is that two interpretations of when remanufacturing occurs in literature would be apparent; confusion over remanfuactuing operations would be limited however given that remanufacturing from the automotive associations perspective is conducted on prodcuts which are not subject to the scope of the ELV directive.

\section{Establishing remanufacturing as a standalone strategy}

At this point, this work has shown how remanufacturing spans across recycling, reuse and recovery terminology of the ELV directive. Being consistent with existing literature and to reduce ambiguity in definition and confusion over product performance, remanufacturing has to be defined as a standalone strategy. 
There are essentially two methods to achieve this, 1) to deconstruct and redefine the existing definitions of recycling and reuse and remove any inference of remanufacturing within these definitions, or 2) insert additional information as part of a remanufacturing definition. Option 1, while the best option to maintain consistency with literature, is not realistic as it would likely face much objection and resistance at the decision level, given that both domestic laws and guidance of member states would likely have to be rewritten as a result of this decision. Option 2 is therefore the more realistic option and the one put forward by the authors. Along with the definition of remanufacturing presented, the authors suggest additional text, similar to the following be inserted.

"If a core has been cleaned, disassembled, had it components restored, or replaced to like new standard or better, reassembled, cleaned, meets or exceeds a rigorous testing standard at least equivalent for a virgin core, and issued with a full warranty, the core is said to have been remanufactured. Remanufacturing is a distinct process and is not typically regarded a generic recycling or reuse operation"

In relation to remanufacturing being conducted at ATF's. The potential of IR having a claim on obtaining all information for environmentally sound treatment of ELV's from vehicle manufacturers, (including the information required to remanufacture) is not able to be resolved in this work. Owing to member states have their own national legislations governing the regulations expected from ATF's and vehicle manufacturers, the current generic description of practices with the EU directive is best left unchecked in this instance. However, this work does highlight potential conflicts which could arise.

\section{Conclusion}

This research has identified that a recent coming together of leading automotive associations has resulted in an agreed upon definition of remanufacturing, and that remanufacturing should occur on products which in their view are not regarded as waste.

Taking this definition into consideration, by firstly ignoring the concept of waste, an investigation of where remanufacturing currently resides in the ELV directive was performed. It was shown that remanufacturing has a presence in recycling, reuse, recovery terminology, with tenuous links between economic operators and treatment facilities. Justification of why remanufacturing should emerge as a standalone strategy within the ELV directive was also documented, with environmental benefits, consistency with literature, reduction in ambiguity of definition and reduction in confusion over performance along with waste reduction benefits discussed.

By incorporating waste into the argument, this research found that at present there is 
no scenario which could satisfy both the automotive associations and the ELV directive, and so direct incorporation of the automotive associations definition of remanufacturing was not possible. The authors suggest remanufacturing is incorporated into the ELV directive via removing the insistence on cores being non-waste, with an abridged version of the automotive associations definition being presented. An unfortunate side effect is two differing interpretations within literature of which stage in the life cycle remanufacturing occurs is developed; this is however unavoidable at present.

Further, a workable solution to bring remanufacturing out from the shadows of generic recycling and reuse terminology was also put forward in this work; a clear remanufacturing process, as recorded via study of industry operations, is given for incorporation into the ELV directive. This inclusion of a remanufacturing process should go some way to starting the process of establishing remanufacturing as a distinct recovery strategy within the ELV directive. 


\section{$\underline{\text { References }}$}

1. Abbey, J.D., Meloy, M.G., Guide, V.D.R., Atalay, S., 2014. Remanufactured products in closed-loop supply chains for consumer goods. Prod. Oper. Manag. 24, 488-503. doi:10.1111/poms. 12238

2. APRA, 2017. What is remanufacturing [WWW Document]. URL https://apra.org/?page=Remanufacturing

3. Automotive Associations, 2016a. Remanufacturing Associations Agree on International Industry Definition [WWW Document]. URL

$\mathrm{http}: / / \mathrm{clepa}$.eu/mediaroom/remanufacturing-associations-agree-international-industrydefinition/ (accessed 2.28.17).

4. Automotive Associations, 2016b. Remanufacturing Associations Agree on International Industry Definition [WWW Document]. URL https://c.ymcdn.com/sites/apra.org/resource/resmgr/European/Reman_press_release_fin al_06.pdf

5. BS 8887-2, 2009. BSI Standards Publication Design for manufacture, assembly, disassembly and end - of - life processing ( MADE ) Part 2 : Terms and definitions.

6. Buxcey, I., 2007. Remanufacturing in the Automotive Industry [WWW Document]. URL http://www.remanufacturing.org.uk/pdf/story/3p71.pdf (accessed 3.29.17).

7. Council of The European Communities, 1975. 75/442/EEC - Council Directive on Waste. Off. J. Eur. Communities L 0442, 1-10.

8. European Action Plan, 2015. European Union Action Plan for the Circular Economy [WWW Document]. URL http://eur-lex.europa.eu/legalcontent/EN/TXT/?uri=CELEX:52015DC0614 (accessed 8.17.16).

9. European Commission, 2015. Directive of the European Parliament and of the Council amending Directive 2008/98/EC on waste [WWW Document]. URL http://www.europarl.europa.eu/oeil/popups/ficheprocedure.do?reference=2015/0275(CO D) $\& \mathrm{l}=\mathrm{en}$

10. European Commission, 2001. Directive 2000/53/EC on End of life vehicles - Guidance Document [WWW Document]. URL http://ec.europa.eu/environment/waste/pdf/guidance_doc.pdf

11. European Parliament and Council, 2012. Directive 2012/19/EU of the European Parliament and of the Council of 4 July 2012 on waste electrical and electronic equipment (WEEE). Off. J. Eur. Union L 197, 38-71. doi:10.3000/19770677.L_2012.197.eng

12. European Parliament and Council, 2008. Directive 2008/98/EC of the European Parliament and of the Council of 19 November 2008 on waste and repealing certain directives (Waste framework. Off. J. Eur. Union L 312, 3-30. doi:2008/98/EC.; 32008L0098

13. European Parliament and Council, 2000. Directive 2000/53/EC - End-of-Life Vehicles. Off. J. Eur. Communities L 269, 34-42. 
14. European Union, 2017. Levels of ELV waste in the EU [WWW Document]. URL http://ec.europa.eu/eurostat

15. Federal Act, 2015. United States Government - Federal repair cost savings act of 2015 [WWW Document]. URL https://www.congress.gov/bill/114th-congress/\%0Asenatebill/565/text/pl (accessed 8.17.16).

16. Gray, C., Charter, M., 2007. Remanufacturing and product design [WWW Document]. URL http://cfsd.org.uk/Remanufacturing and Product Design.pdf

17. Gurler, I., 2011. The Analysis and Impact of Remanufacturing Industry Practices. Int. J. Contemp. Econ. Adm. Sci. 1, 25-39.

18. Hamzaoui-Essoussi, L., Linton, J.D., 2014. Offering branded remanufactured/recycled products: at what price? J. Remanufacturing 4, 1-15. doi:10.1186/s13243-014-0009-9

19. Hatcher, G.D., Ijomah, W.L., Windmill, J.F.C., 2014. Design for remanufacture : a literature review and future research needs. J. Clean. Prod. 19, 2004-2014. doi:10.1016/j.jclepro.2011.06.019

20. Hazen, B.T., Overstreet, R.E., Jones-Farmer, L.A., Field, H.S., 2012. The role of ambiguity tolerance in consumer perception of remanufactured products. Int. J. Prod. Econ. 135, 781-790. doi:10.1016/j.ijpe.2011.10.011

21. Ijomah, W., 2002. A model-based definition of the generic remanufacturing business process. Plymouth University. doi:10026.1/601

22. Ijomah, W., McMahon, C., Hammond, G., Newman, S., 2007. Development of design for remanufacturing guidelines to support sustainable manufacturing. Robot. Comput. Integr. Manuf. 23, 712-719. doi:10.1016/j.rcim.2007.02.017

23. King, A., Burgess, S., Ijomah, W., Mcmahon, C., 2006. Reducing Waste: Repair, Recondition, Remanufacture or Recycle? Sustain. Dev. 267, 257-267. doi:10.1002/sd

24. Lund, R., 1996. The Remanufacturing Industry: Hidden Giant, Boston University press. Boston.

25. Lund, R., Hauser, W., 2010. An American Perspective, in: 5th International Conference on Responsive Manufacturing - Green Manufacturing. doi:10.1049/cp.2010.0404

26. Matsumoto, M., Ijomah, W., 2013. Remanufacturing, in: Kauffman, J., Lee, K. (Eds.), Handbook of Sustainable Engineering. pp. 389-408. doi:10.1007/978-1-4020-8939-8

27. Nasr, N., Thurston, M., 2006. Remanufacturing : A Key Enabler to Sustainable Product Systems, in: Proceedings of the 13th CIRP International Conference on Life Cycle Engineering. pp. 15-18.

28. Paterson, D.A.P., Ijomah, W., Windmill, J., 2016. An analysis of end-of-life terminology in the carbon fiber reinforced plastic industry. Int. J. Sustain. Eng. 9, 130-140. doi:10.1080/19397038.2015.1136361

29. Paterson, D.A.P., Ijomah, W.L., Windmill, J.F.C., 2017. End-of-Life decision tool with emphasis on Remanufacturing. J. Clean. Prod. 148, 653-664.

doi:10.1016/j.jclepro.2017.02.011 
30. Shu, L.H., Flowers, W.C., 1999. Application of a design-for-remanufacture framework to the selection of product life-cycle fastening and joining methods. Robot. Comput. Integr. Manuf. 15, 179-190. doi:10.1016/S0736-5845(98)00032-5

31. Sundin, E., 2004. Product and process design for successful remanufacturing. Linkoping Univeristy.

32. Sundin, E., Lee, H.M., 2012. In what way is remanufacturing good for the environment? In: Matsumoto M., Umeda Y., Masui K., Fukushige S. (eds) Design for Innovative Value Towards a Sustainable Society. Springer, Dordrecht.

33. Sundin, E., Lindahl, M., Ijomah, W., 2009. Product design for product/service systems. J. Manuf. Technol. Manag. 20, 723-753.

doi:http://dx.doi.org/10.1108/17410380910961073

34. Sundin, E., Sakao, T., Lindahl, M., Kao, C.C., Joungerious, B., 2016. ERN report to European Commission "Map of Remanufacturing Business Model Landscape" [WWW Document]. URL https://www.remanufacturing.eu/themes/business-models/

35. Sutherland, J.W., Adler, D.P., Haapala, K.R., Kumar, V., 2008. A comparison of manufacturing and remanufacturing energy intensities with application to diesel engine production. CIRP Ann. - Manuf. Technol. 57, 5-8. doi:10.1016/j.cirp.2008.03.004 


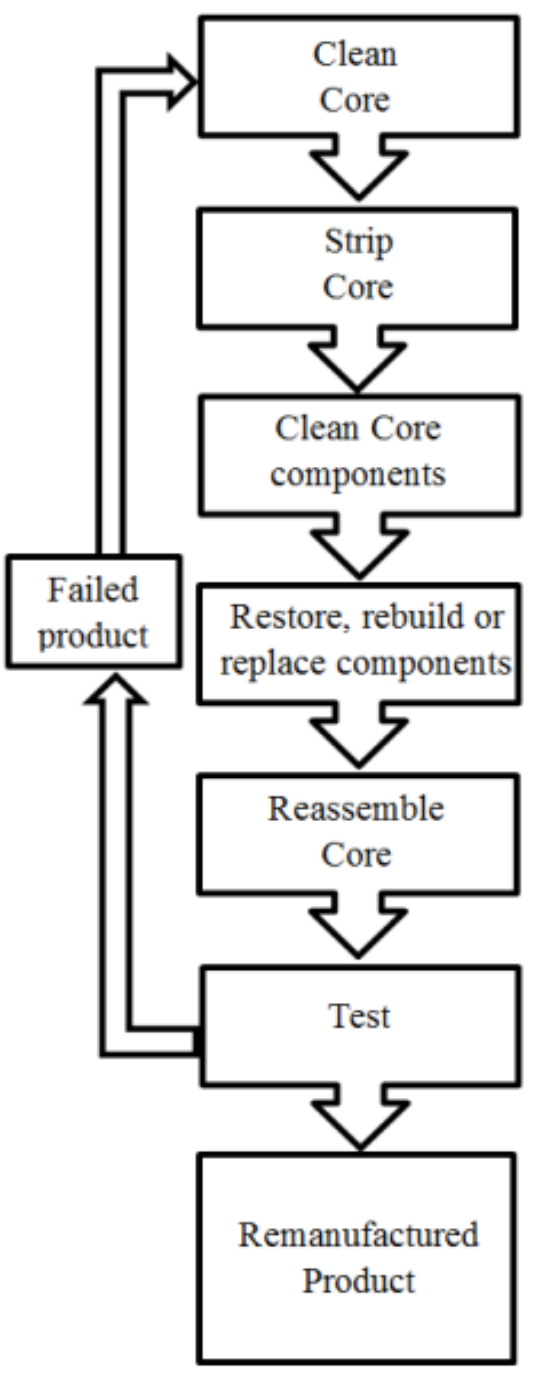

Figure $1-$ The 6 generic steps involved in the remanufacturing process. 


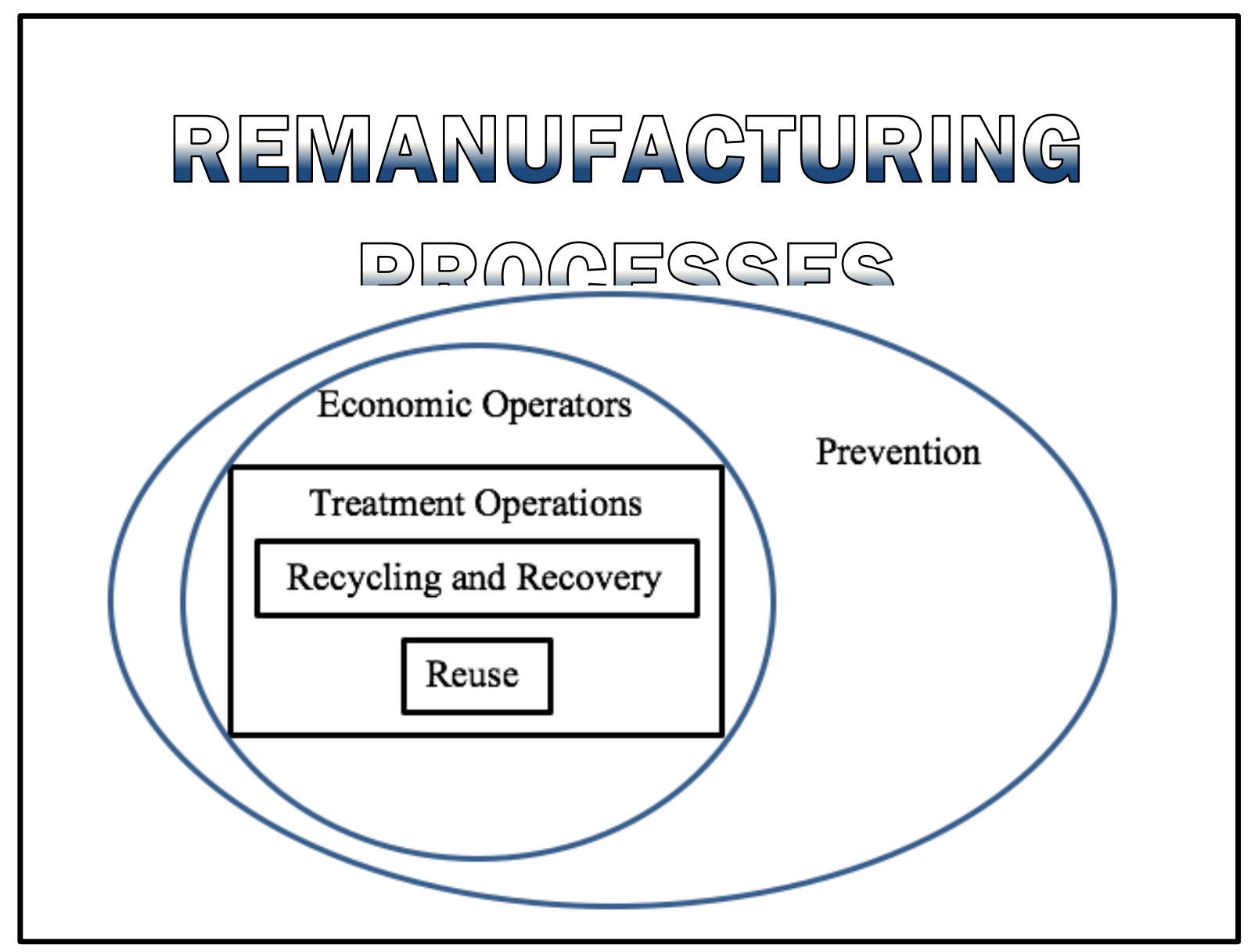

Figure 2 - Various processes and definitions from the ELV which could in theory involve remanufacturing 


\begin{tabular}{|c|c|}
\hline \multicolumn{2}{|r|}{ Remanufacturing Definitions } \\
\hline Source & Definition \\
\hline $\begin{array}{l}\text { Automotive Association } \\
{[3]^{*}}\end{array}$ & $\begin{array}{c}\text { "Remanufacturing is a standardized industrial process* } \\
\text { by which cores are returned to same-as-new, or better, } \\
\text { condition and performance. The process is in line with } \\
\text { specific technical specifications, including engineering, } \\
\text { quality and testing standards. The process yields fully } \\
\text { warranted products." } \\
\text { "*An industrial process is an established process, which } \\
\text { is fully documented, and capable to fulfil the } \\
\text { requirements established by the remanufacturer." }\end{array}$ \\
\hline $\begin{array}{l}\text { British National Standards } \\
\text { Body, [5] }\end{array}$ & $\begin{array}{l}\text { "return a used product to at least its original } \\
\text { performance with a warranty that is equivalent or better } \\
\text { than that of the newly manufactured product" }\end{array}$ \\
\hline European Action Plan [8] & $\begin{array}{l}\text { "A series of manufacturing steps acting on an end-of-life } \\
\text { part or product in order to return it to like-new or better } \\
\text { performance, with corresponding warranty." }\end{array}$ \\
\hline $\begin{array}{l}\text { *Noting that the Automoti } \\
\text { bodies/organizations whic } \\
\text { terminology. These remant } \\
\text { Automotive Suppliers, (MEI } \\
\text { (APRA) the Automotive P } \\
\text { Association of Remanuf } \\
\text { Federation of Engin } \\
\text { Remanufacture Commi }\end{array}$ & $\begin{array}{l}\text { associations is a collection automotive remanufacturing } \\
\text { came together to agree upon common remanufacturing } \\
\text { acturers include; (CLEPA), The European Association of } \\
\text { 4), the Motor \& Equipment Remanufacturers Association, } \\
\text { ts Remanufacturers Association, (ANRAP) the National } \\
\text { turing for Automotive Parts, (FIRM) the International } \\
\text { Remanufacturers and Rebuilders and (CPRA) the } \\
\text { ee of China Association of Automobile Manufactures }\end{array}$ \\
\hline
\end{tabular}

Table 1 - Definitions of remanufacturing cited from literature. 


\begin{tabular}{|c|c|c|}
\hline \multicolumn{3}{|c|}{ Terminology defintions from ELV and WF directive and applicablity to remanufacturing } \\
\hline Section & Definition & Applicibility to remanufacturing \\
\hline 2.1 & $\begin{array}{l}\text { "Vehicle means any vehicle designated as category M1 or N1 defined in Annex } 2 A \text { to Directive } \\
\text { 92/61/EEC, but excluding motor tricycles" }\end{array}$ & N/A \\
\hline $2.2 *$ & $\begin{array}{l}\text { "End of life' vehicles means a vehicle which is waste within the meaning of Article 1(a) of Directive } \\
\text { 75/442/EEC" }\end{array}$ & $\begin{array}{l}\text { Applicable to remanufacturing. Ignoring the issues of } \\
\text { [4] who state 'cores' are not waste, then EoL vehicles } \\
\text { are the products or cores suitable for remanfuacturing. }\end{array}$ \\
\hline 2.3 & $\begin{array}{c}\text { "'Producer' means the vehicle manufacturer or the professional importer of a vehicle into a member } \\
\text { state" }\end{array}$ & $\mathrm{N} / \mathrm{A}$ \\
\hline 2.4 & $\begin{array}{c}\text { "'Prevention' means measures aiming at the reduction of the quantity and the harmfulness for the } \\
\text { environment for end of life vehilces, their materials and substances." }\end{array}$ & $\begin{array}{l}\text { Applicable to remanufacturing. Remanufacturing } \\
\text { accounts for material and energy savings when } \\
\text { compared to new [21,23]. Thus remanufacturing may } \\
\text { be regarded as a prevention operation. }\end{array}$ \\
\hline 2.5 & $\begin{array}{c}\text { "'Treatment' means any activity after the end-of life vehicle has been handed over to a facility for } \\
\text { depollution, dismantling, shearing, shredding, recovery or preparation for disposal of the shredder } \\
\text { wastes, and any other operation carried out for the recovery and/or disposal of the end-of life vehicle } \\
\text { and its components" }\end{array}$ & $\begin{array}{l}\text { Applicable to remanufacturing. Once deposited in a } \\
\text { treatment facility, remanufacturing, which may be } \\
\text { regarded as a recovery operation could occur. Thus } \\
\text { remanufacturing may in some circumstances be } \\
\text { regarded as treatment operation. }\end{array}$ \\
\hline 2.6 & $\begin{array}{c}\text { "reuse' means any operation by which components of end-of life vehicles are used for the same } \\
\text { purpose for which they were conceived" }\end{array}$ & $\begin{array}{l}\text { Applicable to remanufacturing. Considering some parts } \\
\text { in a used prodcut may be suitable for direct reuse in a } \\
\text { remanufactured part, or even lightly restored and re- } \\
\text { used then reuse is applicable to remanfuacturing.. }\end{array}$ \\
\hline 2.7 & $\begin{array}{c}\text { 'recycling' means the reprocessing in a production process of the waste materials for the original } \\
\text { purpose or for other purposes but excluding energy recovery. Energy recovery means the use of } \\
\text { combustible waste as a means to generate energy through direct incineration with or without other } \\
\text { waste but with recovery of the heat; }\end{array}$ & $\begin{array}{l}\text { Applicable to remanufacturing. Recycling involves the } \\
\text { reprocessing in a production process of waste materials } \\
\text { to create new products. Considering } \\
\text { Remanufacturing restores or rebuilds products back to } \\
\text { as good as new condition, then in some instances } \\
\text { remanufacturing processes could fall under some } \\
\text { recycling processes. Note additionally, recycling is a } \\
\text { type of recovery operation. }\end{array}$ \\
\hline 2.8 & 'recovery' means any of the applicable operations provided for in Annex IIB to Directive 75/442/EEC; & \\
\hline $2.8^{* *}$ & $\begin{array}{l}\text { “'recovery' means any operation the principal result of which is waste serving a useful purpose by } \\
\text { replacing other materials which would otherwise have been used to fulfil a particular function, or }\end{array}$ & $\begin{array}{l}\text { Applicable to remanufacturing. Remanufacturing is } \\
\text { able to clearly demonstrated as a recovery operation }\end{array}$ \\
\hline
\end{tabular}




\begin{tabular}{|c|c|c|}
\hline & $\begin{array}{r}\text { waste being prepared to fulfil that function, in the plant or in the wider economy. Annex II sets out a } \\
\text { non-exhaustive list of recovery operations" }\end{array}$ & \\
\hline 2.9 & $\begin{array}{c}\text { "Disposal' means any of the applicable operations provided for in Annex IIA to Directive } \\
75 / 442 / E E C "\end{array}$ & $\begin{array}{l}\text { Not applicable to remanufacturing. Remanufactuing is } \\
\text { not considered a disposal operation. }\end{array}$ \\
\hline 2.10 & $\begin{array}{c}\text { "economic operators' means producers, distributors, collectors, motor vehicle insurance companies, } \\
\text { dismantlers, shredders, recoverers, recyclers and other treatment operators of end-of life vehicles, } \\
\text { including their components and materials" }\end{array}$ & $\begin{array}{l}\text { Applicable to remanufacturing. Recovery operations, } \\
\text { recyclers, and treatment operations may to some degree } \\
\text { be thought of as remanufacturing. Thus in this case } \\
\text { remanufacturers may be thought of as economic } \\
\text { operators. }\end{array}$ \\
\hline 2.11 & $\begin{array}{l}\text { "'hazardous substance' means any substance which fulfils the criteria for any of the following hazard } \\
\text { classes or categories set out in Annex I of Regulation (EC) No 1272/2008 of the European Parliament } \\
\text { and of the Council of } 16 \text { December } 2008 \text { on classification, labelling and packaging of substances and } \\
\begin{array}{r}\text { (a) hazard classes } 2.1 \text { to 2.4, } 2.6 \text { and } 2.7,2.8 \text { types A and B, 2.9, 2.10, 2.12, } 2.13 \text { categories } 1 \text { and 2, } \\
2.14 \text { categories } 1 \text { and } 2,2.15 \text { types A to F; } \\
\text { (b) hazard classes } 3.1 \text { to } 3.6,3.7 \text { adverse effects on sexual function and fertility or on development, } \\
3.8 \text { effects other than narcotic effects, } 3.9 \text { and } 3.10 \text {; } \\
\text { (c) hazard class } 4.1 \text {; } \\
\text { (d) hazard class 5.1; }\end{array}\end{array}$ & Not applicable \\
\hline 2.12 & $\begin{array}{c}\text { “'shredder' means any device used for tearing into pieces or fragmenting end-of life vehicles, } \\
\text { including for the purpose of obtaining directly reusable metal scrap" }\end{array}$ & $\begin{array}{l}\text { Not applicable to remanufacturing. Remanufactuing is } \\
\text { not considered a shredding operation. }\end{array}$ \\
\hline 2.13 & $\begin{array}{l}\text { "'dismantling information' means all information required for the correct and environmentally sound } \\
\text { treatment of end-of life vehicles. It shall be made available to authorised treatment facilities by vehicle } \\
\text { manufacturers and component producers in the form of manuals or by means of electronic media (e.g. } \\
\text { CD-ROM, on-line services).” }\end{array}$ & $\begin{array}{l}\text { Application to remanufacturing. If remanufacturing } \\
\text { falls under what is classed as treatment, then treatment } \\
\text { operators should receive the required information }\end{array}$ \\
\hline \multicolumn{3}{|c|}{$\begin{array}{r}\text { * The definition of waste cited in 75/442/EEC has gone through various revions and is now defined in the WF directive as "any substance or object which the holder discards } \\
\text { or intends or is required to discard" }\end{array}$} \\
\hline
\end{tabular}


Table 2 - Definitions of terminology cited from the End of life vehicles directive (European Parliament and Council, 2000) and waste framework directive (European Parliament and Council, 2008), including the applicability to remanufacturing 